\title{
Repulsion and Day-dreaming: Freud Writing Freud
}

\author{
Kevin Brophy \\ School of Creative Arts, University of Melbourne, Parkville, Vic., Australia
}

Beginning with a reflection on our helplessness in the face of our own discoveries about ourselves in the course of living, this paper outlines the several ways in which psychoanalysis has documented and constructed this helplessness; in turn, Freud's own writings can be read as his own 'helpless' response to early experiences. This paper offers a reading of Freud's 1907 essay, 'Creative writers and day-dreaming' as an unconscious expression of his fear of repulsion (in himself and from others), matched to a desire to seduce the reader. For Freud, though, repulsion is inescapable, for creative writing in his view is never more than foreplay. What then of writing that confronts and unsettles?

doi: $10.2167 /$ new 324.0

Keywords: Freud, creative writing, Coetzee, belief, repulsion, day-dreaming

Four people, two couples, at dinner in a restaurant, were trying to talk about belief. They did not know each other well though they felt they might be moving toward a more intimate or at least a more open friendship. One of the men, we will call him John, said how surprised he was one day to realise he could no longer find in himself any belief in God. He could not make sense of the symbols of religion that had been so central to his life such a short time ago. He was like Lodovico Ariosto's character Orlando who had his wits suddenly taken from him and deposited on the moon. John's partner, we will call her Karen, told the others that despite her scepticism about God she found comfort in the idea of angels. Something in her believed in them, perhaps needed them. The other woman, Maxine, talked of turning against her strict Methodist parents when she was 14 . She gave up her childhood beliefs and refused to go to Sunday school or church. Then in her early 20s she fell in love with the other man at the table making up the foursome, and had married him. This man's brother was a priest and a theologian, and he himself was a lay preacher and a Sunday school teacher when she fell in love with him. He was at that time at the centre of a local Christian community. She had loved him so much that she knew, she said, she would spend the rest of her life with him.

At the table in the restaurant the man who had been a lay preacher laughed and made a joke about Pascal's wager. The joke was a warning not to take this talk about belief too much further. The man who used to be a preacher was in his 60s, dressed neatly in black, his head neatly bald and his skin still smooth, and coloured by the relish for life that showed in his blue eyes. He was an artist, but against most people's expectations he was more sleek than an artist really should be. 
John wanted to press on into the territory of belief. He asked Maxine to say what had happened to her love when the man she married stopped preaching and believing. Maxine said that she remembered the moment when her husband stopped believing. They planned a trip to Europe by ship shortly after they were married, she said, and as the ship set out through the harbour onto the open sea she could tell that suddenly her husband had freed himself from his Christianity. She knew he had left behind him on the shore his beliefs. His body, his physical presence, the way he moved, it all changed then as well as the way he thought.

$* * *$

Do we make our selves or find our selves? Or do we follow our selves through life? Towards the end of his first novel published after being awarded the 2003 Nobel Prize for literature, J.M. Coetzee has his character, Elizabeth Costello, ask 'How does one know what one believes in?' What are we to make of this helplessness when confronted with ourselves? - An atheist who needs the presence of angels, a man who lost his belief as one might lose a wallet, a woman who rebels against all religion then falls in love with a lay preacher, and the preacher who enters so fully into the symbolic experience of a ship leaving a shore that he finds he has left his entire past behind him. In Coetzee's novel Elizabeth Costello says at first that because she is a writer she believes in nothing, then finally and in desperation before her judges, that she believes in frogs.

Those two couples at dinner were not only trying to talk about belief. They were puzzling over this relationship we have with our selves. It has been for nearly a hundred years now a Freudian puzzle and one so intricately constructed that once inside it one cannot help but feel helpless. I want to explore further here the commonplace that Freud's ideas about the self have come to define us (not just describe us); I am proposing that his ideas are not truths but indicators of his own necessary helplessness in the face of himself; and finally I suggest that if we read him as a creative writer (as I think he understood he was) we can comprehend the force of his revelations as akin to the power of literature.

After outlining five psychoanalytically inspired beliefs that have come to permeate our sense of self, I will apply these to a brief outline of the early years of Freud's own life, and suggest that the narrative of his own helplessness is imprinted on his ideas and in his writing. The 1907 essay, 'Creative Writers and Day-dreaming' will be my case study.

Psychoanalysis is a system of knowledge with its own institutions, accreditation procedures, terminology, hierarchies, hair-splitting debates and claims to truth. Careers have been built on this construction of knowledge and the heresies it has made possible. It is not, however, a single discourse of constructed and prescribed knowledge. It has shown a potential for hybridising with related discourses, or we might say like a resistant species-jumping strain of virus it infects and transforms whatever life forms come into contact with it. Like some dinner-table conversations it threatens to undo and outstrip its own subject matter. Professions as diverse as advertising, political 
commentary, biography, cartooning, schooling, child rearing, novel writing, painting, photography and many more have been affected (infected?) by psychoanalytic ideas. Psychoanalysis and in its wake modern psychology have delineated the ways we can perceive and conceive our selves. Even if we have not read a word of Freud's writing, our subjectivity is deeply Freudian.

Freudian theory has been crucial to creating five interlocking significant beliefs about the self.

Firstly, in proposing and describing a topography and an economy of the psyche Freud drew from much of modern society an acceptance of the notion that as individuals we are largely determined and driven by inaccessible unconscious desires (Wittgenstein was one who resisted this notion, the Surrealists of the 1920s and 1930s certainly did, and at times Lacan seemed to resist this idea too though he claimed to be a loyal Freudian). This means we believe the most powerful motivating and shaping energy in our personalities we can never directly experience. We are not in control of ourselves and we don't even know ourselves. Consciousness, like language, has been given to us to obscure the truth. Its appearance of control and knowledge are illusory. What does it mean for us to be convinced of this? Every narrative, we realise, contains another unintended narrative. In René Magritte's words, 'each thing we see hides another' (Torczyner, 1977: 170). When one of the men at the dinner table speaks of his family, saying, 'We are all difficult ... I mean ... we are all different', the others know, they think, that for a moment the competing counternarrative has broken through from an essentially dark unconscious.

It is this insight or contention that made Jacques Derrida's method of deconstruction possible. What was deconstruction if it was not a method based upon the belief that every text will betray itself and be undone by its own unconscious, that is by its unacknowledged expression of its own repressed elements? Our understanding of the indeterminate nature of language and the endless deferral of a text's fixed meaning depends upon this split. The deep uncertainty that we read into texts, we experience in ourselves.

Secondly, through the method of free association, or the talking cure as it came to be known, Freud was drawn to the conviction that childhood sexuality is normal and that this sexuality is the driving force in the formation of our adult personalities. The erotic not only pervades our unconscious life but is expressed in virtually everything we do. We talk about faith, belief or death, but in fact we are talking of beauty, desire, sexuality. It is difficult to know if this is a sudden confinement of the self or the discovery of a new freedom.

Thirdly, though Freud's early work was carried out with hysterical patients, he insisted throughout his writings that there is no clear division between those who are mentally unbalanced and those who are mentally healthy. The difference is merely a matter of degree. All of us have the potential to suffer psychosis and all of us are more or less neurotic. We are all to some degree in conflict, split between ego, superego and id. For the psychoanalyst the neurotic and the psychotic are the normal writ large. For all of us it becomes possible to consider ourselves as potential patients. 
One effect of Freud's work and his theory is the placement of the common person at the centre of attention. He helped open methods of delving into the complexity of the ordinary: dreams, jokes, slips of the tongue, childhood games. History and philosophy can seek to trace the inner and intimate lives of ordinary people in works such as Charles Taylor's Sources of the Self (1989) or Stephen Garton's Histories of Sexuality (2005). It is of course not only Freud who finds complexity and significance in the ordinary, for this has certainly also been the stuff of literature. And it is the impulse behind dinner table conversations that turn to questions of personal belief. Freud's gift was to rediscover, rename and make startling much of what we suspected already.

Fourthly, psychoanalysis has been instrumental in convincing us that the first five or six years of life determine our later development. The key proposition here is Freud's delineation of the family drama encapsulated in the Oedipal crisis through adopting Sophocles' Oedipus Rex as a model for the drama played out in each child's emotional life. Little boys want to murder their fathers and make love to their mothers but fear that their fathers will castrate them if they act on this impulse. In turn little girls believe that their mothers have already castrated them so they turn against their mothers with dismay and hatred. Girls have the social and psychological advantage, however, of knowing they have survived castration: they are as a consequence less rigidly socialised and more fluid in their personalities. Lacan made these early years even more psychologically luminous in psychoanalytic theory through his development of the notion of the mirror stage, a moment that triggers the decisive split between child and mother, self and not-self. Psychoanalysis locates each person within a narrative of self-ignorance.

Finally, Freud's theories seemed to demonstrate how deeply we are formed by our individual and cultural histories. While on the one hand his theories had a biological base in such concepts as instincts and drives, it was the individual stories reported and interpreted from people's experiences that shaped the details of his ideas. It was not surprising that among the four people at the table in the restaurant there was uncertainty and tension over what stories they could tell about themselves, for stories can be far from harmless. Odd details emerged. Maxine said, for instance, after that first journey on a ship her husband suffered extreme nausea every time he went out on a boat again, leaving the others at the table to wonder what continuing cost he might be paying for his suddenly wrenched freedom from belief. Freud's idea that each of us is shaped by a personal history and thus could in theory be reshaped has become a central insight for artists, writers, feminists, educators, all manner of reformists and later theorists of subjectivity. Through its focus on narratives and the shaping of character, Freud's life work in the 23 volumes of his collected psychological writings can read as a huge, ungainly and complex modernist novel.

After psychoanalysis then it becomes impossible to consider any ideas without also considering the unconscious impulses and desires that might be being expressed through them. Though Freud presents himself in his writings 
as one who lays bare uncomfortable but necessary truths, he has given us the means to reconsider his ideas as uncanny expressions of his own repressed desires and fears. Following is a brief outline of some of the salient events of the early years of Freud's life with the intention of bringing him closer to his ideas - ideas that are perhaps closer to beliefs than discoveries. I am here making use of the recent biography of Freud by Louis Breger published in 2000.

Freud was born in 1856 (d. 1939) in Freiburg, Moravia (today Pribor in the Czech Republic), about $200 \mathrm{~km}$ north of Vienna. He was the first child of Jacob and Amalia. Named Sigismund (Sigi: Victor or Victory) Schlomo (after Jacob's recently deceased father), he shortened his name to Sigmund at about the time he began university studies.

His father Jacob had previously been married to a woman who died of tuberculosis and possibly briefly to another woman. Jacob already had two sons from his first marriage (Phillip and Emmanuel).

Freiburg had a population of 4500 . About 130, or 3\%, were Jewish. Only in 1849 , seven years before Freud's birth, had Jewish people been given full legal rights as citizens. For the first time they were able to own land in Moravia.

The family lived in a single rented room. This exposed the young Sigi to many intimate details of family life. Babies were born at home and died at home. Sigi's early life was marked by a series of events that we might call calamities:

- Before Sigi's birth his father Jacob had lost two wives, both to tuberculosis most likely; in addition Jacob's father Schlomo had died six months before Sigi's birth.

- Quickly pregnant again, Amalia gave birth to a second son, Julius, when Sigi was just 11 months old.

- Julius was named after Amalia's brother Julius who had died at 20 of tuberculosis just one month before her second child was born (when Freud was 10 months old).

- About six months after he was born Julius died of an intestinal infection. It is almost certain the death took place in the one-room apartment with the young Freud exposed at least to the family's distress and grief if not to the actual death.

- Amalia might have been depressed, grief-stricken and thus unavailable for some time to the two-year-old Sigi after the losses of her brother and then her second child so close upon each other.

- In addition Amalia suffered from tuberculosis and was sometimes absent at a sanatorium, recovering her health.

- The family was in poverty for most of Sigi's childhood because his father, easygoing and hapless according to Breger, was an unsuccessful businessman; furthermore Sigi was repeatedly displaced in his mother's attention by the regular arrival of babies: five daughters and a last son in six years.

- During his first two and a half years the family employed a nursemaid, a Czech Catholic woman who introduced Freud to the Catholic liturgy by taking him to church and imparted to him some Catholic beliefs such as 
the existence of hell. The young Freud thought he was watching how God acted when he watched the priest during mass. He was attached to this woman but she was suddenly dismissed, arrested and put in prison because she had been caught petty thieving from the family. After she was sent to prison he never saw her again. It was at the same time that his sister Anna was born.

As Breger has pointed out, we could reasonably suppose that overwhelming experiences of loss and grief dominated life in the vulnerable first years for Sigi.

Despite his own lengthy and unprecedented self-analysis recorded in his letters to Wilhelm Fliess and in The Interpretation of Dreams (1900), Freud never articulated the atmosphere of these early years, which we must believe largely determined his adult personality and sexuality - and his ideas.

Louis Breger has suggested that Freud's use of the Oedipal story as the cornerstone of his theories allowed him to construct a comforting myth that obscured the grief, loss, anxiety and helplessness he had actually experienced as a child: in the Oedipal myth the father is a king, with power that challenges the son to heroism and the mother becomes, rather than an absent and sick figure (as it seems Amalia was), a vibrant and loyal lover. I would also want to add here that his use of a playscript by Sophocles as a key to his central insight into the interior of the child's emotional life is an indication of how seriously and as it were irreversibly Freud entered into the literature he read.

Freud was given his early education at home, mainly by his father. It was soon clear that he was intellectually gifted. His greatest gift was with language. At eight years of age he is said to have been reading Shakespeare.

At nine he began formal secondary schooling and soon mastered Latin, Greek, French and English, and later Italian and Spanish. In his final year of secondary school, at 16, he translated Oedipus Rex from Greek to German.

It was through language then, that is in verbal mastery, that Freud first experienced the control he might have longed for as a young child, and discovered a freedom to express himself in ways not permissible in his dayto-day life then or later.

As an example of Freud's desire for control combined with his powerful inhibitions, he showed at this time and throughout his life an aversion to music. If he entered a cafe where a live band was playing it was said he would put his hands over his ears. His mother Amalia was musically gifted and when his sister Anna began learning the piano he told the family that the piano had to go or he would have to leave home. Music was sacrificed in the Freud household for the sake of the study needs of the 'Golden Sigi' as his mother called her eldest son. Later in life Freud would not allow his own children to learn musical instruments.

The little Sigi took a powerful place in his family as his precocious talents emerged: he would tell his sisters what books they should and shouldn't read, and as a nine year old he decided on the name of the last born boy, Alexander (named after the military leader Alexander the Great).

As an adolescent Freud had a number of intimate friendships with boys his own age but little contact with girls despite the presence of five sisters in 
the family household. At 16 he became infatuated with the mother of an 11year-old girl, an infatuation he did not later recall, but replaced with a memory of being in love with the 11-year-old girl.

As a student at the University of Vienna from 1873 to 1882, he studied from 10:00 p.m. to 2:00 a.m. every night. He studied philosophy, science and later physiology. He was desperately poor, continued to live at home in his childhood bedroom now filling with books, and depended on the generosity of some of his admiring teachers, older family friends and wealthier students to help him survive these years.

In 1882, at 26, he fell passionately in love with Martha Bernays, a 20year-old friend of his sisters. They were too poor to consider marriage so they secretly became engaged and he left his badly paid research job at the university to begin an internship at the Vienna General Hospital with a view to establishing himself as a doctor. When Martha and her parents moved to another city and the lovers had to communicate by correspondence, Freud wrote over 900 letters to Martha. Less than 10\% have been released for publication by his estate. His intensely active attachment to Martha (he considered her brother and her mother as rivals) constituted an emotional breakthrough for this overly controlled and controlling young man.

It was also during this time that Freud began experimenting with cocaine as a pain-killer and as treatment for his depression. He found small doses of cocaine lifted his spirits, gave him energy to work and, he considered, improved his intellect. He became close friends with Ernst Flieschl von Maxow, a brilliant young medical researcher who suffered frequent intense pains (through tumours on his nerve endings) from the consequences of a laboratory accident. Freud convinced Flieschl, who was addicted to morphine, to switch to cocaine as a superior pain-killer. He became addicted to both drugs. Freud and Flieschl spent many evenings together sampling their painkillers, Freud injecting his friend when necessary, and talking wildly and intimately about life and ideas and their own fears and anxieties, and about women (Flieschl was also engaged, but would die within six years unmarried). During these evenings Flieschl would be lying in a bath of warm water, presumably naked. This experience of friendship with Flieschl helped loosen Freud further, allowing him to be emotionally open to the anarchic possibilities of the inner world of the self. This experience - of intimacy and love for a fellow human being (reclining like a patient) combined with absolutely honest talk - comes interestingly close to the way the later talking cure of psychoanalysis worked.

This brought Freud to the brink of his turn to psychiatry, the study of hysteria and the development of psychoanalysis.

There are a number of observations to draw from this brief sketch of his early experiences:

- Freud himself was a man of outstanding verbal and literary accomplishment. His early heroes were Shakespeare and Goethe. His passion was for ancient history and ancient Greek literature as well as the contemporary romantic literature of his time. Whatever scientific work he did or scientific system he developed it would be touched by the inspiration he 
found in art and literature. It was through language and literature that he had first experienced himself as a gifted and masterful individual. He would always return to it. Freud's ideas, propositions and methods might best be understood as a system of images and myths, powerful and still influential a hundred years later. It is not surprising that his case studies and essays (always touched by his tendency towards autobiography) make gripping reading for his grasp of narrative complexity and the psychology of character owed much to 19th-century realist fiction.

- Freud's eventual method of psychoanalysis with its necessary transference and its necessarily intimate talk not only reproduced his own most intensely felt emotional exchanges as a young man but rehearsed over and over a situation he would in his professional life insist on controlling (through interpretation and intervention) in order perhaps to continue to keep repressed the possible guilt and regret he felt over losing control of his friendship with Flieschl and later with Wilhelm Fliess. The erotic elements of the psychoanalytic exchange (couch, supine patient, a ritualised love-experience through transference, mastery and mystery attaching to an often silent analyst) in addition continued to allow Freud to explore in professional and scientific safety his own highly controlled but intense homoerotic emotional life. Forty-five years after Flieschl's death a portrait of his friend still hung above the couch in his office, the only photograph on the walls.

- The primal scene he insists is at the base of neuroses and psychoses - the actual or imagined witnessing of parents in the act of intercourse - says more perhaps about particular scenes he was witness to in childhood than any universal psychological structure. The highly controlled erotic trajectory of a psychoanalytic experience might be understood as the infant Freud at last taking control of events in that family room.

- His later overarching proposal that our lives are lived under the power of a death instinct might also be directly related to his own childhood so marked by grief and death. In one of his final essays, 'Analysis Terminable and Interminable' (1937), he cites the aggression of the death instinct as a reason for the limited success of psychoanalysis with some patients.

This is not to deny the power of his insights or the brilliance of his analyses, nor does it mean his ideas are merely a series of wish fulfilments as he would have us believe our dreams are.

$$
* * *
$$

With the above in mind I turn to a reading of Freud's 1907 essay, 'Creative Writers and Day-Dreaming'. It was written during a busy period of professional psychoanalytic work and at a time when he was beginning to produce a series of essays applying psychoanalytic ideas to culture, religion and society. It was prepared as a talk to be given to laypeople at the salon of Hugo Heller, his publisher (Gay, 1988: 307). Like those four people in the restaurant trying, clumsily, to find a way to talk about belief, this essay opens 
with Freud's characteristically humble and awkward acknowledgement that what is about to be discussed is difficult for an outsider, for a layperson like himself. There is even a touch of that jokiness that also came to the four diners as they edged toward the question of their beliefs. Freud's informal but still theatrical self-abasement and enlistment of the reader in a company of ordinary mortals is cute and typical: 'We laymen', he begins. It is simple curiosity that impels the discussion. The early compliments offered to writers are a typical strategy employed by Freud when discussing literature. Where do creative writers get their many stories from? He marvels at the fertility of the imaginations of writers. He even throws in a wishful exclamation that emphasises both the talents of creative writers and the crude earthiness of those who, like him and us, are 'the common run of humanity': 'If we could at least discover in ourselves or in people like ourselves an activity which was in some way akin to creative writing!'

After these two paragraphs of polite admiration he launches a proposition that is attractive, compelling and in itself creatively playful: are not the first traces of imaginative play found in childhood? Indeed, is it possible that every child at play is a creative writer in miniature? For 'the opposite of play is not what is serious but what is real'.

Writers are at play (no accident that actors are called players, that fiction comes from fictio, to make up, to make-believe, and that in the 14th century a fiction was a lie). The point about writers is that they take this play as seriously as children take theirs. It is this seriousness-about-play that links writers with children. This play is as well an intense pleasure, Freud observes - and it is difficult for any of us to give up a pleasure once experienced. We might think here of his knowledge of his own addictive nature after his experiences with cocaine, though equally we can hear in this observation a hint that in fact he considers himself a writer among writers. He too knows the pleasure of this particular kind of creative play, we could conclude.

What the writer discovers through serious play is that many episodes that might be distressing if truly experienced can in the context of fantasied literature provide pleasure to both artist and audience.

In fact, Freud insists, none of us ever give up a pleasure once experienced. If denied it we find other means of experiencing or expressing it. In the case of childhood play we ordinary adults replace it with day-dreams. And as play in childhood was all about growing up and being big, our adult fantasies more often than not are about being even bigger (i.e. more important, more grand) than we are, or by extension and association they are erotically charged.

According to Freud our adult fantasy world of daydreaming becomes a shamefully childish and socially excessive activity. No longer a fantasy of growing-up, it resists the disappointments and realities of adult life. Naturally we keep quiet about this activity and in fact most of us remain barely conscious of it.

But there is a certain class of people who do talk openly about these fantasies: the mentally disturbed. Freud suggests these sufferers can 'tell us nothing that we might not also hear from healthy people': a recurring theme in psychoanalysis, as we have noted. 
After establishing that all of us indulge in fantasies, Freud makes the observation: 'We may lay it down that a happy person never phantasies, only an unsatisfied one'.

He then lays down another seeming fundamental fact about fantasies: 'If phantasies become over-luxuriant and over-powerful, the conditions are laid for an onset of neurosis or psychosis'. This is a threat and a warning to artists and writers who, along with the mentally ill, live for extended periods with luxuriantly detailed fantasies.

Finally Freud reiterates that essentially day-dreams fulfil the same psychological role as night-dreams: wish fulfilment.

The essay breaks here and in the second section he turns to the question of the creative writer. He divides writers into two kinds: those who originate their own material and those who interpret or recycle existing stories.

He focuses on the latter, the less ambitious authors of popular novels. Much of their material recycles the same basic story: hero survives trials and in the end wins the love of a heroine. Not much different, in essence, to day-dreams.

It is worth noting that before reaching his conclusion he has narrowed the field of creative writers to romance authors. This is accomplished almost by sleight of hand. The essay might more accurately be titled, 'Romance Writers and Day-Dreaming'.

Why has he done this? The answer is the same as it is when any theoretically constructed interpretive tool is used to prise a meaning from a text: the text that most easily releases the foregone conclusion will be the one selected for reading. This goes for Marxist criticism, structuralist, poststructuralist, new historicist or postcolonial. Freud, in other words, is no better or worse than other literary critics or theorists.

He does in fact turn briefly to the case of more sophisticated writers and expresses a suspicion that even these writers are working with day-dream wish-fulfilments, only more cleverly or disarmingly presented. The modern novelistic method of the mediated consciousness is, for example, merely another way of presenting an indestructible hero. Even the non-participating spectator-character so common in the modernist novel is also a recurrent daydreaming position. Note that from being a self-proclaimed lay person in awe of creativity at the beginning of the essay Freud has moved to a position that boxes even the most modern and sophisticated fiction writer in with the common daydreamer on the basis of a theoretical interpretive structure.

This neat package, however, throws up the conundrum that this essay has been all along moving towards: why is it that we find it boring when people tell us their predictable and clichéd day-dreams and yet we become entranced by the day-dreams (as Freud has defined literature) of certain writers?

What is it that writers do to this material to make it so fascinating? Is it that they distract us with beauty and pleasure while they deliver the predictable day-dream wish fulfilment?

At this point Freud writes of day-dreams as repellant. They 'repel us'. There is 'a feeling of repulsion in us' in response to them. This is, I think, a surprisingly personal reaction to day-dreams. Most of us, as I've suggested above, would find them boring, idle, predictable, but not repellant. Freud speaks of this repulsion in connection with the 'barriers that rise between each 
single ego and the others'. Freud was always aware of the etymology of words and their poetic force as images. It is a doubly emphasised reaction to the daydreaming presence of other egos. I think of 'the others' as those siblings who arrived after him in the small family room in Freiburg (and later the rivals he imagined around his fiancée Martha), and the repulsion he might have felt at being exposed not only to his parents' sexual life but to the presence of death. Is Freud saying he is repulsed by exposure to people's day-dreams, or is it that he fears others will be repulsed if his own day-dreams were exposed? Does this word allow an underlying unconscious narrative to surface briefly?

The writer, he suggests, has two strategies to disarm these barriers of repulsion. The first is to soften the egoistic character of his dreams. I take this to mean the writer projects the actions of the day-dream out into fictional characters, often highly diverting and colourful. We forget the writer is actually writing about himself. What is this if it is not a description of what Freud has done himself in this essay? With every statement he has made about day-dreams we might want to ask Freud if he speaks of himself or out of knowledge of himself. When he separates himself so emphatically from the 'creative writer' at the beginning surely this is a sign of both his own daydream of being a creative writer, and of the fact that creative writing is what he is doing himself in any case. The second strategy for disarming barriers of repulsion is the offering of pleasure to the reader. Freud makes a witty erotic association by suggesting that what writers give us is foreplay only much later followed by the strange coitus of our own 'deeper psychical' wish fulfilment. The foreplay, fore-pleasure or incentive bonus is aesthetic. Its value to us is the removal of shame so that we can enjoy our own fantasies. At the end of this essay uncannily the creative writer becomes an agent (or at least a catalyst) of psychic healing similar to a psychoanalyst. There seems to be a strange confession embedded in this conclusion, one that indicates Freud does understand the deep pleasure of release connected with creative writing. He is that which he is describing.

Nearly a hundred years later creative writing and creative writers are established presences in modern universities. There is no shortage of students wanting to fill classes, lectures and workshops in creative writing. Freud's respectful separation of the layperson from the creative writer becomes less convincing in a world where thousands of students are doing creative writing as if it was not only a dream in itself but a discipline and a profession almost anyone can aspire to. Creative writing, though, remains for the moment an uncanny phenomenon in universities because, I suggest, while it gives prominence to the strangely expressive power of unconscious desire and individual talent, it is bound by a commitment to critical intellect as long as it aspires to a place in tertiary education. Its connection with day-dreams (including erotic possibilities) and its unruly 'power to say everything' in Derrida's (1992: 37) phrase give it an attractive edginess in the academy. It has become a testing ground for the mind and the self. Almost anything could be said in a creative writing class (though nearly always the predictable is what emerges). Freud, for his part, finally seems to want to tie the creative writer down to the predictable. His essay raises the possibility that creative writing 
will always defer the most important issues, the deepest pleasures, the most real confrontations with ourselves.

His essay ends with this distraction or disturbance, this complication thrown up by reference to creative writing as foreplay. Is writing always then a form of incomplete seduction? Is truncated pleasure its point? Is it never a real experience? Is the overvaluing of writing or literature a form of perversion? (remembering that Freud considered foreplay a dangerous activity when extended). But this final colourful flourish obscures the fact that not all cases of creative writing have been accounted for. There is the case of that creative writing that is manifestly not a wish fulfilment. J.M. Coetzee's novel, Elizabeth Costello, is such a case. It is beautifully written, pleasurably intelligent, voyeuristically intimate, but what it offers us is not permission to go on with our own day-dreams. Its heroine, Elizabeth Costello, along with most of the other characters, confronts us with insoluble dilemmas, shameful accusations, disturbing ideas, an inevitable failure of belief, politically and morally messy questions about evil, obscenity and the possible harm that stories can do. Coetzee's book is so confronting that I had to read it twice in quick succession to be sure I understood the problems it had raised that so unsettled my life. This disturbance is an experience I associate mostly with literature and sometimes with dreams. This is the kind of writing (the kind of dream) Freud found most difficult to analyse and explain as mere wish fulfilment, but clearly it is the kind of writing he aspired to produce.

Coetzee's novel is replete with facts and logic, as is Freud's writing, and always the reader moves on through the pages partly on account of the pleasure offered by this writing and this mind. But in the end Coetzee and Freud come back to a discussion of belief. There are angels or there are ships that will transport us from the past to an unimagined future, there are wholly other ways of being in the world if you can manage, despite your helplessness, the trick of becoming that self you do not yet realise you might be. Freud's case finally does not rest upon evidence, argument or facts but upon our willingness to go along with him. And this is the case with every writer.

At the end of the dinner in that restaurant each couple went home, as Craig Raine has written, to

hide in pairs

and read about themselves -

in colour, with their eyelids shut.

\section{Correspondence}

Any correspondence should be directed to Kevin Brophy, School of Creative Arts, University of Melbourne, Arts Centre Building, cnr Swanston and Grattan Streets, Parkville, Vic. 3010, Australia (kevinjb@unimelb.edu.au).

\section{References}

Breger, L. (2000) Freud: Darkness in the Midst of Vision. New York: Wiley. Coetzee, J.M. (2003) Elizabeth Costello. New York: Knopf.

Derrida, J. (1992) D. Attridge (ed.) Acts of Literature. London: Routledge. 
Freud, S. (1991) Creative writers and day-dreaming (1908 [1907]). In Standard Edition of the Complete Psychological Works of Sigmund Freud, Volume IX (A. Freud, A. Strachey and A. Tyson, trans.) London: Hogarth Press.

Garton, S. (2005) Histories of Sexuality: Antiquity to Sexual Revolution. New York: Equinox.

Gay, P. (1988) Freud: A Life for our Time. London: Papermac Macmillan.

Raine, C. (1988 (1979)) A Martian sends a postcard home. In R. Ellmann and R. O'Clair (eds) The Norton Anthology of Modern Poetry. New York: Norton.

Taylor, C. (1989) Sources of the Self: The Making of the Modern Identity. Cambridge: Cambridge University Press.

Torczyner, H. (1977) Magritte: Ideas and Images. New York: Harry N. Abrams. 


\section{University Library}

- MINERVA A gateway to Melbourne's research publications

Minerva Access is the Institutional Repository of The University of Melbourne

Author/s:

BROPHY, KEVIN

Title:

Repulsion and day-dreaming: Freud writing Freud

Date:

2006

Citation:

Brophy, K. (2006). Repulsion and day-dreaming: Freud writing Freud. New Writing: The International Journal for the Practice and Theory of Creative Writing, 3(2), 132-144.

Publication Status:

Published

Persistent Link:

http://hdl.handle.net/11343/34645

File Description:

Repulsion and day-dreaming: Freud writing Freud 


\section{University Library}

\section{- M M I N E R VA A gateway to Melbourne's research publications}

Minerva Access is the Institutional Repository of The University of Melbourne

Author/s:

Brophy, $\mathrm{K}$

Title:

Repulsion and Day-dreaming: Freud Writing Freud

Date:

2006-01-01

Citation:

Brophy, K. (2006). Repulsion and Day-dreaming: Freud Writing Freud. NEW WRITING-THE INTERNATIONAL JOURNAL FOR THE PRACTICE AND THEORY OF CREATIVE WRITING, 3 (2), pp.132-144. https://doi.org/10.2167/new324.0.

Persistent Link:

http://hdl.handle.net/11343/25398 